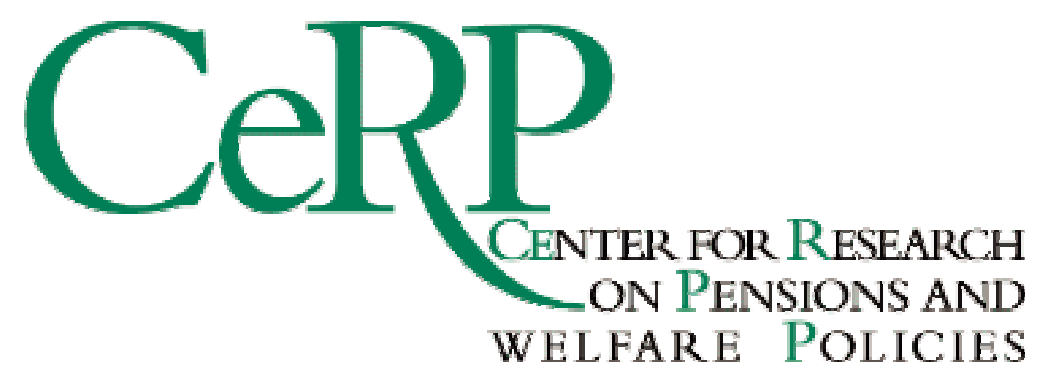

Working Paper 55/06

ON THE MEASUREMENT OF INTRA-GENERATIONAL LIFETIME REDISTRIBUTION IN PENSION SYSTEMS

Antonio Abatemarco 


\title{
On the Measurement of Intra-Generational Lifetime Redistribution in Pension Systems
}

\author{
A. Abatemarco \\ Center for Research on Pensions and Welfare Policies (CeRP), Via Real Collegio, \\ 30 - 10024 Moncalieri (TO). Tel.: +39011 6705047, E-mail: \\ abatemarco@cerp.unito.it.
}

\begin{abstract}
It is known that existing measures of intra-generational (within cohorts) redistribution induced by pension schemes may prove highly misleading in the presence of inter-generational (between cohorts) redistribution. In this paper we show that the Kakwani progressivity index, extended to account for both positive and negative individual tax liabilities, is a non-distorted measure of intra-generational redistribution in pension systems. The relevance of the distortion induced by inter-generational transfers is empirically shown in the comparison between pre- and post-reform Italian pension schemes from 1992 to 2004.
\end{abstract}

Keywords: redistribution, progressivity, pension

JEL: D30, D63, H55

\section{Introduction}

The measurement of lifetime redistribution induced by pension systems has attracted the interest of many researchers (Creedy et al., 1993; Nelissen, 1995; Oshio, 2002; Disney, 2004; Borella and Coda Moscarola, 2006). Two types of redistribution have been widely investigated: inter-generational and intra-generational. The latter concerns the lifetime redistribution induced by the pension system among members of the same cohort. The former, instead, refers to the lifetime redistribution between cohorts, which is the gap, in the aggregate, between the present value of contributions and benefits at retirement

* I am grateful to Margherita Borella, Onorato Castellino, Flavia Coda Moscarola, Elsa Fornero and Peter J. Lambert for very helpful comments and suggestions. The usual disclaimer applies. 
for each cohort as a whole. This is strictly related to financial sustainability issues. $^{1}$

The measurement of intra-generational redistribution is known to be distorted in the presence of inter-generational redistribution. That is, over- or under-estimation may occur in generous or parsimonious pension systems. This problem turns out to be particularly relevant in the case of mature steady-state pay-as-you-go (PAYG) pension schemes, since inter-generational redistribution is automatically entailed whenever the discount rate and the earnings growth rate differ (Aaron, 1986; Creedy et al., 1993).

In the existing literature, intra-generational redistribution induced by pension schemes is usually measured through well known indexes in the field of fiscal progressivity, ie. the Reynolds and Smolensky (1977) and the effective progression index (Musgrave and Thin, 1948). In order to capture the sole intra-generational component, at the preliminary stage, the observed data are usually re-scaled in such a way as to eliminate the gap, in the aggregate, between the present value of contributions and benefits for each cohort as a whole (Kennedy, 1990; Creedy et al., 1993).

In this paper we propose a more rigorous approach, where the distortion induced by inter-generational redistribution is avoided by "manipulating" the normative properties of the progressivity index, not the observed data. With this purpose in mind, we show that the Kakwani (1977) progressivity index - as adequately extended to the scenario with both positive and negative tax liabilities - allows for the measurement of intra-generational redistribution independently of inter-generational redistribution.

The paper is organized as follows. In section 2 we highlight the two main components of the redistribution induced by pension systems (intra- and intergenerational). Also, the impact of inter-generational redistribution on progressivity comparisons is discussed. In section 3, in order to capture the sole intragenerational component, we suggest an extension of the Kakwani index allowing for (i) both positive and negative tax liabilities and (ii) independence of inter-generational redistribution. In section 4 , in order to highlight empirically the magnitude of the distortion induced by inter-generational redistribution, we calculate the Kakwani (non-distorted) and the Reynolds-Smolensky (distorted) progressivity indexes on micro-simulated pre- and post-reform data for the Italian pension system. Section 5 concludes.

\footnotetext{
1 From an ex-ante point of view, intra-generational redistribution might be intended as an insurance against strong income disparities in the working life "that is not available in the market" (Diamond, 2004). Inter-generational redistribution, instead, is mostly aimed at partial/full insurance against demographic and financial risks (Smith, 1982).
} 


\section{Progressivity comparisons}

A pension system is said to be redistributive when it is not actuarially fair, and vice versa. The redistribution can be of the intra- or/and the intergenerational kind. In order to capture the intra-generational lifetime redistribution induced by pension systems, two different concepts of lifetime income at retirement are required, ie. theoretical and actual. The former indicates the lifetime income an individual would enjoy under the hypothesis of an $a c$ tuarially fair pension system, where, for each individual, the present value of contributions at retirement perfectly matches the present value of benefits at retirement. In particular, theoretical lifetime incomes are usually defined under the no pension system hypothesis, ie. contributions are capitalized at the market rate of return in the absence of behavioral responses. The latter, instead, refers to the lifetime income actually received by each income unit under the existing regulation of the pension system. In contrast with the distribution of theoretical lifetime incomes, here the present values of contributions and benefits at retirement do not necessarily coincide with each other both at the individual and at the aggregate (cohort) level.

Given the distribution of theoretical and actual lifetime incomes, the main insight behind progressivity comparisons is straightforward: the pension system is progressive whenever theoretical lifetime incomes (pre-tax) are less equally distributed than the actual one (post-tax), and vice versa. In addition, pension system A is more progressive than B's whenever it is more lifetime inequality-reducing than the latter, and vice versa. In this sense, pension schemes can be compared over time or across countries. ${ }^{2}$

Two progressivity indexes are usually implemented for the measurement of intra-generational redistribution induced by pension systems, ${ }^{3}$ the ReynoldsSmolensky (RS) and the effective progression index (EP). ${ }^{4}$ The former is defined as the difference between the two Gini indexes $(\mathrm{G})$ calculated, respectively, on the distribution of theoretical and actual lifetime incomes at retirement. In other words, RS measures the equality gain due to the existence of the pension system. It is positive in the case of progressive pension systems, and vice versa. The EP is defined as the ratio (not the difference) between actual and theoretical equality, ie. it is informationally (not ordinally)

$\overline{2}$ In this paper we strictly refer to effective, not structural (local) progressivity measures (Lambert, 1993). On the implications of different theoretical (pre-tax) income distributions in effective progressivity comparisons see Lambert and Pfahler (1992).

${ }^{3}$ In this paper, we strictly refer to complete orderings as obtained through progressivity indexes. However, for the sake of robustness, Lorenz dominance conditions should be preferred (Lambert, 1999; Dardanoni and Lambert, 2000).

4 For a general overview on progressivity indexes see Kiefer (1984). 
equivalent to the former. ${ }^{5}$

Let's consider a population of $n$ equally-aged individuals, living two periods each, one as worker and one as retiree. The theoretical and actual lifetime incomes at retirement for a generic pension scheme are $\ell_{i}^{*}=y_{i}(1-c)(1+r)+p_{i}^{*}=$ $y_{i}(1+r)$ and $\ell_{i}=y_{i}(1-c)(1+r)+p_{i}$, where $r, c, y, p^{*}$ and $p$ indicate, respectively, the discount rate, the contribution rate, the working income, the theoretical and actual pension benefits. Given the vectors of theoretical and actual lifetime incomes at retirement for a generic cohort $h\left(\ell^{*}\right.$ and $\left.\ell\right)$, progressivity can be measured sic et simpliciter as $R S=G\left(\ell^{*}\right)-G(\ell)$. Unfortunately, such a progressivity index depends on the generosity/parsimony of the pension system with respect to cohort $h .{ }^{6}$ This fact is particularly relevant in the case of PAYG pension systems, since at maturity (and steady-state) intergenerational redistribution is automatically involved whenever $g \neq r$ where $g$ is the earnings growth rate, ie. $p_{i}=c y_{i}(1+g) \neq p_{i}^{*} \cdot{ }^{7}$

Let's indicate by $t_{i}=\left(p_{i}^{*}-p_{i}\right)$ the $i$ th tax liability (if $t_{i}>0$ ) or gift (if $t_{i}<0$ ) due to the pension system and by $T=\sum_{i=1}^{n} t_{i}$ the parsimony/generosity with respect to the $n$-sized cohort $h$. The former is the tax/gift paid/received by

5 In this paper we stick to "lifetime-based progressivity comparisons", which is the most common approach in the field of pension systems. However, a multi-variate (multi-period) approach might be required in order to achieve more rigorous progressivity orderings. First, lifetime progressivity automatically entails averaging of the redistributive transfers at each period. Second, by virtue of lifetime progressivity, maximum progressivity of the pension scheme would be achieved whenever the vector of actual pension benefits perfectly offsets the income disparities in the working life (-1 correlation between incomes in the working and elder life), which is not a generally accepted definition of maximum progressivity.

6 An additional problem in the measurement of intra-generational redistribution in the field of pension system consists of the timing approach. By virtue of the expost approach, individual profiles (eg. income, household size, longevity) are known for each individual under certainty conditions. By virtue of the ex-ante approach, current pension systems may be assessed today with respect to the expected working life and longevity. The two approaches are not necessarily equivalent to each other. For instance, it is usually observed that, ex-ante, the redistribution induced by the positive correlation between working income and longevity would be totally neglected.

7 This type of intergenerational redistribution is inherent in a PAYG scheme, and it may be looked at as the burden suffered by all future generations as a counterpart to the subsidy enjoyed by the elderly generation when the scheme was first introduced (see Kotlikoff (1987), p. 416). In place of the "no pension system hypothesis" adopted in the text, theoretical incomes might thus be defined under the "null solidarity hypothesis", by which contributions are capitalized at the discount rate or the earnings growth rate depending on the participation to funded or unfunded schemes. By the latter, the difference between the earnings growth rate and the discount rate in a mature steady-state PAYG system would not be source of inter-generational redistribution. 
each individual, while the latter is the tax/gift paid/received by each cohort as a whole (inter-generational redistribution). Then, the $i$ th actual lifetime income at retirement can be defined as the result of a tax structure (inherent in the pension system) by which $\ell_{i}=\ell_{i}^{*}-t_{i}$. In order to capture the sole intra-generational redistribution, we may want the progressivity index to be independent of the size of $T$. In other words, indicating by $\mathcal{P}$ a generic progressivity index, it should be the case that

$$
\mathcal{P}\left(\ell, \ell^{*}, T\right)=\mathcal{P}\left(\ell^{\prime}, \ell^{*} \lambda T\right) \quad \forall \lambda \in \Re, \lambda \neq 0
$$

where $\ell_{i}^{\prime}=\ell_{i}^{*}-\lambda t_{i}$. In particular, when comparing the pension schemes of two equally sized societies A and B, if (1) holds, then it must be the case that

$$
\begin{aligned}
\mathcal{P}\left(\ell^{A}, \ell^{A^{*}}, T^{A}\right) & >\mathcal{P}\left(\ell^{B}, \ell^{B^{*}}, T^{B}\right) \Longleftrightarrow \mathcal{P}\left(\ell^{A}, \ell^{A^{*}}, T^{A}\right)>\mathcal{P}\left(\ell^{B^{\prime}}, \ell^{B^{*}}, T^{A}\right) \\
& \Longleftrightarrow \mathcal{P}\left(\ell^{A^{\prime}}, \ell^{A^{*}}, T^{B}\right)>\mathcal{P}\left(\ell^{B}, \ell^{B^{*}}, T^{B}\right)
\end{aligned}
$$

that is, progressivity orderings are independent of the size of inter-generational redistribution. Unfortunately, it can be shown that RS and EP do not satisfy (1), so that a distortion of intra-generational redistribution would be naturally involved unless $T=0 .{ }^{8}$

In the existing literature, in order to capture the sole intra-generational redistribution, at the preliminary stage, the contribution rate is usually re-scaled in such a way to eliminate inter-generational redistribution (Creedy et al., 1993). In other words, in a two-period economy where each individual lives one period as worker and one period as retiree, given $\ell$ from the observed data, lifetime incomes at retirement are re-scaled such that $\hat{\ell}_{i}=y_{i}(1-\hat{c})(1+r)+p_{i}$, where $\hat{c}=\alpha c$ and $\alpha=\left[\sum_{i} p_{i}\right] /\left[\sum_{i} c y_{i}(1+r)\right]$ automatically imply $T^{\prime}=0$. Next, $\mathrm{RS}$ and/or EP are computed on the transformed data. Unfortunately, this solution does not allow for independence of inter-generational redistribution, unless of particular circumstances. ${ }^{9}$

$\overline{8 \text { Both }} \mathrm{RS}$ and EP are invariant to scale transformations of the vector of actual lifetime incomes, not tax liabilities. Given $\ell_{i}^{\prime}=\ell_{i}^{*}-\lambda t_{i}, G\left(\ell^{\prime}\right) \neq G(\ell)$, and, as a result, $R S\left(\ell, \ell^{*}, T\right) \neq R S\left(\ell^{\prime}, \ell^{*} \lambda T\right)$ as well as $E P\left(\ell, \ell^{*}, T\right) \neq E P\left(\ell^{\prime}, \ell^{*} \lambda T\right)$.

9 Given $y, p \in \Re_{+}^{n}, p^{*}=c y(1+r), \ell^{*}=y(1-c)(1+r)+p^{*}, \ell=\ell^{*}-\left(p^{*}-p\right)$ and $\ell^{\prime}=\ell^{*}-\lambda\left(p^{*}-p\right)$, then $R S\left(\hat{\ell}, \ell^{*}, T\right)=R S\left(\hat{\ell}^{\prime}, \ell^{*}, \lambda T\right) \forall \lambda$ iff $\exists \gamma \in \Re: \hat{\ell}^{\prime}=\gamma \hat{\ell} \forall y, p$. Given $p^{*} \neq p$, there is no unique scalar $(\gamma)$ satisfying this condition. In the case of mature steady state PAYG pension systems, instead, given $\ell=y(1-c)(1+r)+$ $c y(1+g)$ and $\ell^{\prime}=y(1-c)(1+r)+c y\left(1+g^{\prime}\right)$, with $g^{\prime}$ such that $T^{\prime}=\lambda T$, it must be the case $\hat{\ell}^{\prime}=\hat{\ell}=y(1+r)$, ie. $R S\left(\hat{\ell}, \ell^{*}, T\right)=R S\left(\hat{\ell}^{\prime}, \ell^{*}, \lambda T\right)=0 \forall \lambda$. 


\section{The measurement of intra-generational redistribution}

Intra- and inter-generational redistribution in pension systems strongly differ from each other, so that it might be convenient to separate these two sources of redistribution, and, in particular, to define a measure of intragenerational redistribution which is independent of the inter-generational component as specified in (1).

In the existing literature on fiscal progressivity, the Kakwani (1977) progressivity index $(\mathrm{K})$ has been widely used for a very similar purpose, ie. independence of the average tax rate. However, since pension schemes are usually characterized by both positive and negative individual tax liabilities, this index has been mostly disregarded for the measurement of lifetime redistribution (Coronado et al., 2000). Here, instead, we observe that K - as extended to negative tax liabilities - fits the measurement of intra-generational redistribution.

$\mathrm{K}$ is defined as the difference between the concentration index $(\mathrm{C})$, calculated on the distribution of tax liabilities, and the Gini of the distribution of theoretical lifetime incomes at retirement (pre-tax incomes). In other words, $\mathrm{K}$ measures the disproportionality of tax liabilities with respect to the distribution of theoretical lifetime incomes at retirement (Lambert, 1999). Given non-negative individual tax liabilities, it is defined in $\left[-\left(1+G\left(\ell^{*}\right)\right),\left(1-G\left(\ell^{*}\right)\right)\right]$ and it is positive in the case of progressive pension schemes. In particular, for our purposes, it is worth observing that

$K\left(\ell^{*}, \ell, T\right)=C\left(\ell^{*}-\ell\right)-G\left(\ell^{*}\right)=C\left(\ell^{*}-\ell^{\prime}\right)-G\left(\ell^{*}\right)=K\left(\ell^{*}, \ell^{\prime}, \lambda T\right) \quad \forall \lambda>0$

where, once again, $\ell_{i}^{\prime}=\ell_{i}^{*}-\lambda t_{i}$. In other words, if tax liabilities are nonnegative, then $\mathrm{K}$ is independent of inter-generational redistribution as specified in (1). In addition, given the average tax rate $\bar{t}=T / \sum_{i} \ell_{i}^{*}$, it is known that $R S=[\bar{t} /(1-\bar{t})] K$.

Unfortunately, $\mathrm{K}$ is not clearly defined in the presence of negative tax liabilities, which is a very recurrent case in the field of pension systems. In particular, for our purposes it should be taken into account that (i) tax liabilities might be negative $\left(t_{i}<0\right)$ for some individuals (the concentration curve of tax liabilities might be initially negative), and, even more, (ii) the average tax rate might be negative.

Point (i) is not sufficient to jeopardize either the opportunity for Gini-based inequality orderings or the relationship between RS and K. However, as observed in Schutz (1951) and Chen et al. (1982), since the concentration curve is expected to be negative for the poorest income units, the concentration index is not necessarily bounded in $[-1,1]$ any longer $(C \in[-\infty,+\infty]) .{ }^{10}$ As a result, in the presence of both positive and negative tax liabilities, $K$ is defined

\footnotetext{
$\overline{{ }^{10} \text { Let's }}$ consider an income vector with maximum concentration $x:=\{0,10\}$. Intuitively, if negative incomes are allowed, then concentration can be furthermore enhanced through some poor-to-rich transfer, eg. $\hat{x}:=\{-1,11\}$.
} 
in $[-\infty,+\infty]$.

Similarly, in the case of negative average tax liabilities (ii), K's progressivity orderings are not invalidated, but some observations need to be made. In order to be progressive the pension system must reduce inequality with respect to the distribution of actual lifetime incomes at retirement. As observed in (Duclos, 2000), if the average tax rate is negative, then the pension system is progressive whenever the concentration curve of (negative) tax liabilities lies nowhere below the Lorenz curve of theoretical lifetime incomes at retirement, ie. if subsidies are inequality reducing. Formally, given $\sum_{i=1}^{n}\left(\ell_{i}^{*}-\ell_{i}\right)<0$, the pension system is progressive if and only if

$$
\frac{\mu_{j}\left(\ell^{*}\right)-\mu_{j}(\ell)}{\mu\left(\ell^{*}\right)-\mu(\ell)} \geq \frac{\mu_{j}\left(\ell^{*}\right)}{\mu\left(\ell^{*}\right)} \quad \forall j:=1, \ldots, n
$$

where $\mu$ and $\mu_{j}$ are the averaging operators as calculated on, respectively, the whole distribution and the first $j$ income units increasingly-ordered with respect to $\ell^{*}\left(\mu_{j}(\ell)=\frac{1}{n} \sum_{i=1}^{j} \ell_{i}\right)$. It is worth observing that the pension system is progressive if subsidies are equally shared among members of the population and, in the absence of individual positive tax liabilities, it is maximally progressive if the whole subsidy is received by the poorest income unit in terms of theoretical lifetime income at retirement. Then, given the Lorenz ordering in (2), $\mathrm{K}$ can be generalized in such a way to allow for both negative average tax liabilities and independence of inter-generational redistribution as follows.

Claim 3.1 Given (i) $\left(\ell^{*}-\ell\right) \in \Re^{n}$ with $\sum_{i=1}^{n}\left(\ell_{i}^{*}-\ell_{i}\right) \neq 0$ and (ii) $\ell$ orderingpreserving with respect to $\ell^{*}$, then

$$
K= \begin{cases}C\left(\ell^{*}-\ell\right)-G\left(\ell^{*}\right), & \text { for } \sum_{i}\left(\ell_{i}^{*}-\ell_{i}\right)>0 \Longrightarrow R S=\frac{\bar{t}}{1-\bar{t}} K, \\ G\left(\ell^{*}\right)-C\left(\ell^{*}-\ell\right) & \text { for } \sum_{i}\left(\ell_{i}^{*}-\ell_{i}\right)<0 \Longrightarrow R S=\frac{\bar{s}}{1-\bar{s}} K\end{cases}
$$

where $\bar{s}=\frac{\sum_{i=1}^{n}\left(\ell_{i}-\ell_{i}^{*}\right)}{\sum_{i=1}^{n} \ell_{i}}$ and $K \in[-\infty,+\infty]$.

Proof 3.1 The extension of the well known (3a) to (3b) is straightforward from (i) the Lorenz dominance condition in (2) and (ii) $C(t)=1-2 \int_{0}^{1} L(t) d t=$ $1-2 \int_{0}^{1} L(-t) d(-t)=C(-t)(L(\cdot)$ is an even function $) .{ }^{11}$

In order to highlight the distortion of progressivity orderings when RS is implemented in the presence of inter-generational redistribution, it is worth ob-

\footnotetext{
${ }^{11}$ It is worth observing that if the concentration curve is above the bisectrix, then the concentration index is two-times the (negative) area between the bisectrix and the concentration curve.
} 
serving that

$$
K= \begin{cases}\frac{\sum_{i=1}^{n} \ell_{i}}{\sum_{i=1}^{n} t_{i}} R S & \text { if } \bar{t}>0, \\ -\frac{\sum_{i=1}^{n} \ell_{i}^{*}}{\sum_{i=1}^{n} t_{i}} R S & \text { if } \bar{t}<0\end{cases}
$$

that is, as it might be expected, the distortion of $\mathrm{RS}$ is more likely to occur whenever the two societies to be compared strongly differ in the (relative) size of inter-generational redistribution.

\section{A case study: pension reforms in Italy}

Given the analytical framework above, it might be argued that the distortion induced by inter-generational redistribution is not large enough to jeopardize comparisons in terms of intra-generational redistribution. In order to verify the relevance of the distortion we compare Italian pension schemes from 1992 to 2004. In particular, we consider six different schemes. The first is the pre-1992 scheme. The others are obtained by introducing one reform at each step up to the 2004 scheme, so that the latter involves all reforms from the 1992 to the 2004. The Italian case is particularly convenient for our purposes since pension reforms in the last two decades have seriously reduced the size of inter-generational redistribution. Before 1992, the Italian pension system was extremely generous: on average, the gap between the present value of contributions and benefits at retirement was almost 30\% of lifetime income at retirement (CeRPSIM). After (i) the transition from a defined-benefit (DB) to a notional defined-contribution (NDC) pension formula (1995), (ii) three reforms aimed (mostly) at the definition of more stringent eligibility rules for entitlement to pension benefits (1992, 1997 and 2004) and (iii) one reform introducing a means-tested supplementary old-age allowance for poor retirees (2002), the gap above has decreased from $30 \%$ to $2 \%$ of lifetime income at retirement for younger cohorts. ${ }^{12}$ As a result of such a huge change in the size of inter-generational redistribution, a serious distortion of standard progressivity measures might be expected, especially in comparing the pre-1992 with the 2004 pension scheme.

For our analysis we use the same micro-data used by Borella and Coda Moscarola (2006), which are generated through a stochastic dynamic micro-simulation model by cohorts (CeRPSIM) . ${ }^{13}$ The degree of progressivity after each reform is calculated for six different cohorts (born in 1945, 1955, 1965, 1975, 1985,

\footnotetext{
$\overline{12}$ For details on the nature of the pension reforms refer to Borella and Coda Moscarola (2006).

${ }^{13}$ In particular, Borella and Coda Moscarola (2006) analyze the impact of Italian pension reforms in terms of overall redistribution, that is, the progressivity induced
} 
1995) of 15,000 individuals each retiring from the year 2000 onwards. Looking at the slow transition from the DB to the NDC scheme (1995 reform), the cohorts may be grouped into three categories. For the former $(1945,1955)$, the 1995 reform does not (mostly) apply, so that the DB scheme (mostly) applies. For the 1965 and 1975 cohorts, instead, the pro-rata mechanisms is introduced, by which both DB and NDC apply proportionally. Finally, the NDC fully applies to the 1985 and 1995 cohorts.

In order to highlight the magnitude of the distortion induced by intergenerational redistribution, in this section we analyze the change in progressivity induced by each of the five pension reforms in Italy from 1992 to 2004 (1992, 1995, 1997, 2002, 2004) using two different approaches. First, we calculate progressivity in the presence of the distortion induced by inter-generational redistribution through RS. Next, intra-generational redistribution is calculated by $\mathrm{K}(3)$.

When comparing progressivity orderings as obtained under RS (tab. 1 appendix) and K (tab. 2 appendix), some of the progressivity orderings are found reversed, meaning that the distortion induced by inter-generational redistribution is found empirically relevant. In Fig. 1 we compare the progressivity orderings as obtained under RS and K. RS-based comparisons are reported below the main diagonal, while K-based ones are above the main diagonal. By ">" and "<" we indicate, respectively, progressivity orderings. For instance, for cohort 1995, the " $>$ " in the third line (95) of the first column (P92) indicates that progressivity in the pre-1992 scheme - as measured by RS - is larger than after the two reforms (1992 and 1995), ie. the two reforms as a whole have been progressivity reducing $(R S(P 92)>R S(95))$. Equivalently, the " $>$ " in the third column (95) of the first line (P92) column indicates the pre-1992 scheme is more progressive than the 1995's one, ie. $K(P 92)>K(95)$. In this example, RS and K order equivalently the pre-1992 and the 1995 pension schemes, meaning that the presence of inter-generational redistribution is not sufficient to jeopardize comparisons in terms of intra-generational redistribution. More in general, if each matrix in Fig. 1 is perfectly symmetric, then the distortion induced by inter-generational redistribution is empirically

by both intra- and inter-generational redistribution as a whole. CeRPSIM-data on education, entrance in the labor market, marriage and mortality are gained through Monte Carlo simulations. Earnings profiles have been estimated on a panel of administrative data (INPS archive) separately for employees and self-employed workers, men and women, white and blue collars. Earnings histories are estimated as a result of two components: a deterministic, group-specific age profile and an unobserved component modelled as an autoregressive process with an individual effect. In the pension module for the computation of benefits under different regulations, individuals are assumed to claim their pension benefits as soon as they are eligible. For our computation observations are dropped whenever $\ell$ is ordering-reversing with respect to $\ell^{*}$. These cases are found very rare (no more than a hundred on 15,000 observations for each cohort) and more recurrent for the eldest cohorts. 


\begin{tabular}{|c|c|c|c|c|c|c|}
\hline RSIK & P92 & 92 & 95 & 97 & 02 & 04 \\
\hline P92 & RSIK & $<$ & $>$ & $>$ & 4 & 4 \\
\hline 92 & $>$ & RSIK & $>$ & $>$ & $\succ$ & $<$ \\
\hline 95 & $>$ & $>$ & RSIK & $>$ & $<$ & $<$ \\
\hline 97 & $>$ & $>$ & $>$ & RSIK & $<$ & $<$ \\
\hline 02 & $>$ & $>$ & $<$ & $<$ & RSIK & $>$ \\
\hline 04 & $>$ & $>$ & $<$ & $<$ & $>$ & RSIK \\
\hline
\end{tabular}

Cohort: 1975

\begin{tabular}{|c|c|c|c|c|c|c|}
\hline RSIK & P92 & 92 & 95 & 97 & 02 & 04 \\
\hline P92 & RSIK & $\succ$ & $\succ$ & $\succ$ & $\succ$ & $<$ \\
\hline 92 & $>$ & RSIK & $\succ$ & $\succ$ & $<$ & $<$ \\
\hline 95 & $>$ & $>$ & RSIK & $>$ & $<$ & $<$ \\
\hline 97 & $>$ & $>$ & $>$ & RSIK & $<$ & $<$ \\
\hline 02 & $>$ & $>$ & $>$ & $>$ & RSIK & $<$ \\
\hline 04 & $>$ & $>$ & $>$ & $>$ & $>$ & RSIK \\
\hline
\end{tabular}

Cohort: 1955

\begin{tabular}{|c|c|c|c|c|c|c|}
\hline RSIK & P92 & 92 & 95 & 97 & 02 & 04 \\
\hline P92 & - & - & - & - & - & - \\
\hline 92 & - & RSIK & $>$ & $>$ & $<$ & $<$ \\
\hline 95 & - & $>$ & RSIK & $>$ & $<$ & $<$ \\
\hline 97 & - & $>$ & $>$ & RSIK & $<$ & $<$ \\
\hline 02 & - & $>$ & $>$ & $>$ & RSIK & $<$ \\
\hline 04 & - & $>$ & $>$ & $>$ & $<$ & RSIK \\
\hline
\end{tabular}

\begin{tabular}{|c|c|c|c|c|c|c|}
\hline RSIK & P92 & 92 & 95 & 97 & 02 & 04 \\
\hline P92 & RSIK & $<$ & $>$ & $>$ & $<$ & $<$ \\
\hline 92 & $>$ & RSIK & $>$ & $>$ & $\succ$ & $<$ \\
\hline 95 & $>$ & $>$ & RSIK & $>$ & $<$ & $<$ \\
\hline 97 & $>$ & $>$ & $>$ & RSIK & $<$ & $<$ \\
\hline 02 & $>$ & $>$ & $<$ & $<$ & RSIK & $>$ \\
\hline 04 & $>$ & $>$ & $<$ & $<$ & $>$ & RSIK \\
\hline
\end{tabular}

Cohort: 1965

\begin{tabular}{|c|c|c|c|c|c|c|}
\hline RSIK & P92 & 92 & 95 & 97 & 02 & 04 \\
\hline P92 & RSIK & $>$ & $>$ & $>$ & $<$ & $<$ \\
\hline 92 & $>$ & RSIK & $>$ & $>$ & $<$ & $<$ \\
\hline 95 & $>$ & $>$ & RSIK & $>$ & $<$ & $<$ \\
\hline 97 & $>$ & $>$ & $>$ & RSIK & $<$ & $<$ \\
\hline 02 & $>$ & $<$ & $<$ & $<$ & RSIK & $<$ \\
\hline 04 & $>$ & $<$ & $<$ & $<$ & $<$ & RSIK \\
\hline
\end{tabular}

\begin{tabular}{|c|c|c|c|c|c|c|}
\hline \multicolumn{10}{c}{ Cohort: 1945 } \\
\hline RSIK & P92 & 92 & 95 & 97 & 02 & 04 \\
\hline P92 & - & - & - & - & - & - \\
\hline 92 & - & RSIK & $>$ & $<$ & $<$ & $<$ \\
\hline 95 & - & $>$ & RSIK & $>$ & $<$ & $<$ \\
\hline 97 & - & $<$ & $>$ & RSIK & $<$ & $<$ \\
\hline 02 & - & $<$ & $<$ & $<$ & RSIK & $<$ \\
\hline 04 & - & $<$ & $<$ & $<$ & $<$ & RSIK \\
\hline
\end{tabular}

$<,>$ : matching progressivity orderings (RS and KAK)

$\checkmark, \mathbf{4}$ : contrasting progressivity orderings (RS and KAK)

*P92 = pre-1992 pension scheme

**Data not available for 1945 and 1955 cohorts in the pre-1992 scheme (Borella and Coda Moscarola, 2006)

Fig. 1. Progressivity comparisons. Source: author's computations on CeRPSIM data.

irrelevant. However, this is not the case (in fig. 1 contrasting orderings are reported in bold "

If we exclude the 1975 cohort, whose public workers have been seriously advantaged $^{14}$ with respect to the other cohorts by the 1992 reform, most of the reversed orderings occur when comparing pension schemes which seriously differ in the size of inter-generational redistribution, ie. the pre-1992 (or 1992) and the 2002 (or 2004) pension schemes. In addition, as it might be expected, reversed orderings are more recurrent for the 1995 and 1985 cohorts - fully subjected to the NDC scheme - than for the 1975 and 1965 cohorts - participating proportionally (pro-rata) to both the DB and NDC scheme - or, for the 1945 and 1955 cohorts - mostly subjected to the DB (pre-1992) pension scheme. ${ }^{15}$

\footnotetext{
${ }^{14}$ Because of the extremely high returns on the portion of contributions accrued in the old DB pension scheme (Fornero and Castellino, 2001).

${ }^{15}$ In terms of pension policies, it is worth observing that when comparing by $\mathrm{K}$ the original (pre-1992) and the final pension scheme (2004), despite the transition from DB to NDC, progressivity is increased. Such an apparently striking result supports previous empirical evidences about the presence of a relevant source of perverse
} 


\section{Concluding remarks}

Existing approaches for the measurement of intra-generational redistribution are known to be distorted in the presence of inter-generational redistribution. In this paper we show that, in order to eliminate such a distortion, the Kakwani progressivity index might be appropriately extended in such a way to allow simultaneously for (i) both positive and negative tax liabilities and (ii) independence of inter-generational redistribution. In this sense, the Kakwani progressivity index seems to match all major requirements for the measurement of progressivity in tax-benefit schemes in general.

In order to highlight the empirical relevance of the distortion induced by inter-generational redistribution, we analyze the impact on progressivity of five pension reforms in Italy in the last two decades (1992-2004). We show that, at least for the Italian case, comparisons of reforms in terms of progressivity would prove seriously misleading whenever inter-generational redistribution is not appropriately taken into account. In particular, our results suggest that the Kakwani index is definitely required when pension systems to be compared strongly differ in the relative size of the inter-generational component.

Future research will concentrate on the multi-dimensional generalization of the Kakwani progressivity index. This would allow to capture by-period, instead of lifetime-based (ie. averaged) redistribution.

redistribution in the old DB Italian pension scheme (Castellino, 1995). 
APPENDIX

\begin{tabular}{|c|c|c|c|c|c|c|}
\hline $\mathbf{R S}$ & $\mathbf{P - 9 2}$ & $\mathbf{9 2}$ & $\mathbf{9 5}$ & $\mathbf{9 7}$ & $\mathbf{0 2}$ & $\mathbf{0 4}$ \\
\hline $\mathbf{1 9 4 5}$ & - & 0.004 & 0.004 & 0.004 & 0.007 & 0.007 \\
$\mathbf{1 9 5 5}$ & - & 0.014 & 0.008 & 0.008 & 0.012 & 0.015 \\
$\mathbf{1 9 6 5}$ & 0.040 & 0.013 & 0.005 & 0.005 & 0.016 & 0.016 \\
$\mathbf{1 9 7 5}$ & 0.039 & 0.022 & 0.010 & 0.010 & 0.024 & 0.023 \\
$\mathbf{1 9 8 5}$ & 0.042 & 0.023 & 0.001 & 0.001 & 0.010 & 0.006 \\
$\mathbf{1 9 9 5}$ & 0.045 & 0.025 & 0.001 & 0.001 & 0.010 & 0.005 \\
\hline
\end{tabular}

Tab.1. Reynolds-Smolensky progressivity indexes by cohort and pension system. Source: CeRPSIM.

\begin{tabular}{|c|c|c|c|c|c|c|}
\hline $\mathbf{K}$ & $\mathbf{P - 9 2}$ & $\mathbf{9 2}$ & $\mathbf{9 5}$ & $\mathbf{9 7}$ & $\mathbf{0 2}$ & $\mathbf{0 4}$ \\
\hline $\mathbf{1 9 4 5}$ & - & 0.016 & 0.015 & 0.016 & 0.027 & 0.027 \\
$\mathbf{1 9 5 5}$ & - & 0.048 & 0.040 & 0.040 & 0.061 & 0.085 \\
$\mathbf{1 9 6 5}$ & 0.101 & 0.057 & 0.047 & 0.047 & 0.134 & 0.150 \\
$\mathbf{1 9 7 5}$ & 0.100 & 0.118 & 0.257 & 0.257 & 0.403 & 0.441 \\
$\mathbf{1 9 8 5}$ & 0.110 & 0.132 & 0.030 & 0.030 & 0.467 & 0.284 \\
$\mathbf{1 9 9 5}$ & 0.120 & 0.149 & 0.060 & 0.060 & 0.482 & 0.285 \\
\hline
\end{tabular}

Tab.2. Kakwani progressivity indexes by cohort and pension system. Source: CeRPSIM. 


\section{References}

Aaron, H., 1986. Comment. In: Wise, D. (Ed.), Pensions, Labor and Individual Choice. NBER, pp. 215-221.

Borella, M., Coda Moscarola, F., 2006. Redistribution in the Italian pension system. Giornale degli Economisti (forthcoming) .

Castellino, O., 1995. Redistribution between and within generations in the Italian social security system. Ricerche Economiche 49, 317-327.

Chen, C.-N., Tsaur, T.-W., Rhai, T.-S., 1982. The Gini coefficient and negative income. Oxford Economic Papers 34 (3), 473-478.

Coronado, J., Fullerton, D., Glass, T., 2000. The progressivity of social security. NBER Working Papers 7520.

Creedy, J., Disney, R., Whitehouse, E., 1993. The earnings-related state pension, indexation and lifetime redistribution in the UK. Review of Income and Wealth $39(3)$.

Dardanoni, V., Lambert, P., 2000. Progressivity comparisons. IFS Working Papers (W00/18).

Diamond, P., 2004. Social security. The American Economic Review 94 (1), 1-24.

Disney, R., 2004. Are contributions to public pension programmes a tax on employment? Economic Policy 39, 267-311.

Duclos, J.-Y., 2000. Gini indices and the redistribution of income. International Tax and Public Finance 7, 141-162.

Fornero, E., Castellino, O., 2001. La riforma del sistema previdenziale italiano. Il Mulino.

Kakwani, N., 1977. Measurement of tax progressivity: an international comparison. Economic Journal 87, 71-80.

Kennedy, B., 1990. Financial consistency in longitudinal microsimulation: homemaker pensions re-examined. Review of Income and Wealth 36 (2), 215-221.

Kiefer, D., 1984. Distributional tax progressivity indexes. National Tax Journal 37, 497-513.

Kotlikoff, L., 1987. Social security. The new Palgrave - A dictionary of economics Vol. 4, Londond, Macmillan.

Lambert, P., 1993. The Distribution and Redistribution of Income: A Mathematical Analysis. Manchester University Press.

Lambert, P., 1999. Redistributional effects of progressive income taxes. In: Silber, J. (Ed.), Handbook of Income Inequality Measurement. Kluwer Academic Publishing, pp. 485-509.

Lambert, P., Pfahler, W., 1992. Income tax progression and redistributive effect: the influence of changes in the pre-tax income distribution. Public Finance/Finances Publiques 47, 1-16.

Musgrave, R., Thin, T., 1948. Income tax progression, 1929-48. Journal of Political Economy 56 (6), 498-514.

Nelissen, J., 1995. Lifetime income redistribution by the old-age state pension in the Netherlands. Journal of Public Economics 58, 429-451.

Oshio, T., 2002. Intra-age, inter-age and lifetime income redistribution. Journal of Population and Social Security 1 (1).

Reynolds, M., Smolensky, E., 1977. Post-fisc distributions of income in the 1950, 
1961 and 1970. Public Finance Quarterly 11, 109-120.

Schutz, R., 1951. On the measurement of income inequality. The American Economic Review 41 (1), 107-122.

Smith, A., 1982. Inter-generational transfers as social insurance. Journal of Public Economics 19, 97-106. 
Our papers can be downloaded at:

$\underline{\text { http://cerp.unito.it/publications }}$

\section{CeRP Working Paper Series}

\begin{tabular}{|c|c|c|}
\hline $\mathrm{N}^{\circ} 1 / 00$ & Guido Menzio & Opting Out of Social Security over the Life Cycle \\
\hline $\mathrm{N}^{\circ} 2 / 00$ & $\begin{array}{l}\text { Pier Marco Ferraresi } \\
\text { Elsa Fornero }\end{array}$ & $\begin{array}{l}\text { Social Security Transition in Italy: Costs, Distorsions and (some) } \\
\text { Possible Correction }\end{array}$ \\
\hline$N^{\circ} 3 / 00$ & $\begin{array}{l}\text { Emanuele Baldacci } \\
\text { Luca Inglese }\end{array}$ & $\begin{array}{l}\text { Le caratteristiche socio economiche dei pensionati in Italia. } \\
\text { Analisi della distribuzione dei redditi da pensione (only available } \\
\text { in the Italian version) }\end{array}$ \\
\hline $\mathrm{N}^{\circ} 4 / 01$ & Peter Diamond & Towards an Optimal Social Security Design \\
\hline $\mathrm{N}^{\circ} 5 / 01$ & Vincenzo Andrietti & $\begin{array}{l}\text { Occupational Pensions and Interfirm Job Mobility in the } \\
\text { European Union. Evidence from the ECHP Survey }\end{array}$ \\
\hline $\mathrm{N}^{\circ} 6 / 01$ & Flavia Coda Moscarola & $\begin{array}{l}\text { The Effects of Immigration Inflows on the Sustainability of the } \\
\text { Italian Welfare State }\end{array}$ \\
\hline $\mathrm{N}^{\circ} 7 / 01$ & Margherita Borella & $\begin{array}{l}\text { The Error Structure of Earnings: an Analysis on Italian } \\
\text { Longitudinal Data }\end{array}$ \\
\hline $\mathrm{N}^{\circ} 8 / 01$ & Margherita Borella & $\begin{array}{l}\text { Social Security Systems and the Distribution of Income: an } \\
\text { Application to the Italian Case }\end{array}$ \\
\hline$N^{\circ} 9 / 01$ & Hans Blommestein & $\begin{array}{l}\text { Ageing, Pension Reform, and Financial Market Implications in } \\
\text { the OECD Area }\end{array}$ \\
\hline $\mathrm{N}^{\circ} 10 / 01$ & $\begin{array}{l}\text { Vincenzo Andrietti and Vincent } \\
\text { Hildebrand }\end{array}$ & $\begin{array}{l}\text { Pension Portability and Labour Mobility in the United States. } \\
\text { New Evidence from the SIPP Data }\end{array}$ \\
\hline$N^{\circ} 11 / 01$ & $\begin{array}{l}\text { Mara Faccio and Ameziane } \\
\text { Lasfer }\end{array}$ & $\begin{array}{l}\text { Institutional Shareholders and Corporate Governance: The Case } \\
\text { of UK Pension Funds }\end{array}$ \\
\hline $\mathrm{N}^{\circ} 12 / 01$ & Roberta Romano & $\begin{array}{l}\text { Less is More: Making Shareholder Activism a Valuable } \\
\text { Mechanism of Corporate Governance }\end{array}$ \\
\hline$N^{\circ} 13 / 01$ & Michela Scatigna & Institutional Investors, Corporate Governance and Pension Funds \\
\hline $\mathrm{N}^{\circ} 14 / 01$ & Thomas H. Noe & Investor Activism and Financial Market Structure \\
\hline $\mathrm{N}^{\circ} 15 / 01$ & Estelle James & $\begin{array}{l}\text { How Can China Solve ist Old Age Security Problem? The } \\
\text { Interaction Between Pension, SOE and Financial Market Reform }\end{array}$ \\
\hline$N^{\circ} 16 / 01$ & $\begin{array}{l}\text { Estelle James and } \\
\text { Xue Song }\end{array}$ & $\begin{array}{l}\text { Annuities Markets Around the World: Money's Worth and Risk } \\
\text { Intermediation }\end{array}$ \\
\hline $\mathrm{N}^{\circ} 17 / 02$ & $\begin{array}{l}\text { Richard Disney and } \\
\text { Sarah Smith }\end{array}$ & $\begin{array}{l}\text { The Labour Supply Effect of the Abolition of the Earnings Rule } \\
\text { for Older Workers in the United Kingdom }\end{array}$ \\
\hline $\mathrm{N}^{\circ} 18 / 02$ & Francesco Daveri & $\begin{array}{l}\text { Labor Taxes and Unemployment: a Survey of the Aggregate } \\
\text { Evidence }\end{array}$ \\
\hline $\mathrm{N}^{\circ} 19 / 02$ & $\begin{array}{l}\text { Paolo Battocchio } \\
\text { Francesco Menoncin }\end{array}$ & $\begin{array}{l}\text { Optimal Portfolio Strategies with Stochastic Wage Income and } \\
\text { Inflation: The Case of a Defined Contribution Pension Plan }\end{array}$ \\
\hline$N^{\circ} 20 / 02$ & Mauro Mastrogiacomo & Dual Retirement in Italy and Expectations \\
\hline $\mathrm{N}^{\circ} 21 / 02$ & $\begin{array}{l}\text { Olivia S. Mitchell } \\
\text { David McCarthy }\end{array}$ & Annuities for an Ageing World \\
\hline
\end{tabular}


Chris Soares Mark Warshawsky

$\mathrm{N}^{\circ} 23 / 02 \quad$ Ermanno Pitacco

$\mathrm{N}^{\circ}$ 24/02 Laura Ballotta Steven Haberman

$\mathrm{N}^{\circ} 25 / 02$ Edmund Cannon Ian Tonks

$N^{\circ} 26 / 02 \quad$ E. Philip Davis

$N^{\circ}$ 27/02 Reinhold Schnabel

$N^{\circ} 28 / 02 \quad$ Luca Spataro

N ${ }^{\circ} 29 / 02 \quad$ Marco Taboga

$\mathrm{N}^{\circ} 30 / 03 \quad$ Bas Arts

Elena Vigna

№ 31/03 Giacomo Ponzetto

N ${ }^{\circ} 32 / 04 \quad$ Angelo Marano

Paolo Sestito

$\mathrm{N}^{\circ} 33 / 04 \quad$ Elsa Fornero

Carolina Fugazza

Giacomo Ponzetto

N 34/04 Chourouk Houssi

$\mathrm{N}^{\circ}$ 35/04 Monika Bütler

Olivia Huguenin

Federica Teppa

$N^{\circ} 36 / 04 \quad$ Laurence J. Kotlikoff

$N^{\circ} 37 / 04 \quad$ Jay Ginn

№ 38/05 Carolina Fugazza

Federica Teppa

No 39/05 Anna Rita Bacinello

$N^{\circ} 40 / 05 \quad$ Carolina Fugazza

Massimo Guidolin

Giovanna Nicodano

$\mathrm{N}^{\circ}$ 41/05 Massimo Guidolin

Giovanna Nicodano

$\mathrm{N}^{\circ} 42 / 05 \quad$ Margherita Borella

Flavia Coda Moscarola

$\mathrm{N}^{\circ} 43 / 05 \quad$ John Beshears

James J. Choi

David Laibson

Brigitte C. Madrian
Annuity Risk: Volatility and Inflation Exposure in Payments from Immediate Life Annuities

Longevity Risk in Living Benefits

Valuation of Guaranteed Annuity Conversion Options

The Behaviour of UK Annuity Prices from 1972 to the Present

Issues in the Regulation of Annuities Markets

Annuities in Germany before and after the Pension Reform of 2001

New Tools in Micromodeling Retirement Decisions: Overview and Applications to the Italian Case

The Realized Equity Premium has been Higher than Expected: Further Evidence

A Switch Criterion for Defined Contribution Pension Schemes

Risk Aversion and the Utility of Annuities

Older Workers and Pensioners: the Challenge of Ageing on the Italian Public Pension System and Labour Market

A Comparative Analysis of the Costs of Italian Individual Pension Plans

Le Vieillissement Démographique :

Problématique des Régimes de Pension en Tunisie

What Triggers Early Retirement. Results from Swiss Pension Funds

Pensions Systems and the Intergenerational Distribution of Resources

Actuarial Fairness or Social Justice?

A Gender Perspective on Redistribution in Pension Systems

An Empirical Assessment of the Italian Severance Payment (TFR)

Modelling the Surrender Conditions in Equity-Linked Life Insurance

Investing for the Long-Run in European Real Estate. Does Predictability Matter?

Small Caps in International Equity Portfolios: The Effects of Variance Risk.

Distributive Properties of Pensions Systems: a Simulation of the Italian Transition from Defined Benefit to Defined Contribution The Importance of Default Options for Retirement Saving Outcomes: Evidence from the United States 


\begin{tabular}{|c|c|c|}
\hline $\mathrm{N}^{\circ} 44 / 05$ & Henrik Cronqvist & Advertising and Portfolio Choice \\
\hline$N^{\circ} 45 / 05$ & Claudio Campanale & Increasing Returns to Savings and Wealth Inequality \\
\hline$N^{\circ} 46 / 05$ & $\begin{array}{l}\text { Annamaria Lusardi } \\
\text { Olivia S. Mitchell }\end{array}$ & $\begin{array}{l}\text { Financial Literacy and Planning: Implications for Retirement } \\
\text { Wellbeing }\end{array}$ \\
\hline $\mathrm{N}^{\circ} 47 / 06$ & $\begin{array}{l}\text { Michele Belloni } \\
\text { Carlo Maccheroni }\end{array}$ & $\begin{array}{l}\text { Actuarial Neutrality when Longevity Increases: An Application } \\
\text { to the Italian Pension System }\end{array}$ \\
\hline $\mathrm{N}^{\circ} 48 / 06$ & $\begin{array}{l}\text { Onorato Castellino } \\
\text { Elsa Fornero }\end{array}$ & $\begin{array}{l}\text { Public Policy and the Transition to Private Pension Provision in } \\
\text { the United States and Europe }\end{array}$ \\
\hline $\mathrm{N}^{\circ} 49 / 06$ & Mariacristina Rossi & $\begin{array}{l}\text { Examining the Interaction between Saving and Contributions to } \\
\text { Personal Pension Plans. Evidence from the BHPS }\end{array}$ \\
\hline $\mathrm{N}^{\circ} 50 / 06$ & $\begin{array}{l}\text { Andrea Buffa } \\
\text { Chiara Monticone }\end{array}$ & $\begin{array}{l}\text { Do European Pension Reforms Improve the Adequacy of } \\
\text { Saving? }\end{array}$ \\
\hline $\mathrm{N}^{\circ} 51 / 06$ & Giovanni Mastrobuoni & $\begin{array}{l}\text { The Social Security Earnings Test Removal. Money Saved or } \\
\text { Money Spent by the Trust Fund? }\end{array}$ \\
\hline $\mathrm{N}^{\circ} 52 / 06$ & $\begin{array}{l}\text { Luigi Guiso } \\
\text { Tullio Jappelli }\end{array}$ & Information Acquisition and Portfolio Performance \\
\hline $\mathrm{N}^{\circ} 53 / 06$ & Giovanni Mastrobuoni & $\begin{array}{l}\text { Labor Supply Effects of the Recent Social Security Benefit Cuts: } \\
\text { Empirical Estimates Using Cohort Discontinuities }\end{array}$ \\
\hline $\mathrm{N}^{\circ} 54 / 06$ & $\begin{array}{l}\text { Annamaria Lusardi } \\
\text { Olivia S. Mitchell }\end{array}$ & $\begin{array}{l}\text { Baby Boomer Retirement Security: The Roles of Planning, } \\
\text { Financial Literacy, and Housing Wealth }\end{array}$ \\
\hline $\mathrm{N}^{\circ} 55 / 06$ & Antonio Abatemarco & $\begin{array}{l}\text { On the Measurement of Intra-Generational Lifetime } \\
\text { Redistribution in Pension Systems }\end{array}$ \\
\hline
\end{tabular}

